\title{
Reduced Vibrations and Noise During Grinding
}

\author{
Krzysztof Nowacki, Karolina Łakomy \\ Silesian University of Technology, Poland
}

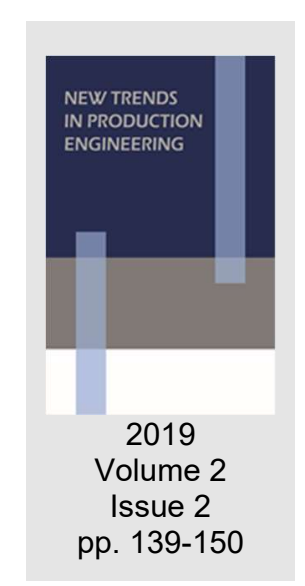

Date of submission to the Editor: 09/2019

Date of acceptance by the Editor: 11/2019

\section{MECHANICAL VIBRATIONS IN THE WORK ENVIRONMENT}

Vibrations are a nuisance or harmful factor that occurs in most industrial processes. In the literature, the concept of vibration is defined as vibrations occurring in mechanical systems, having a harmful effect on the environment, human or construction (Uzarczyk, 2006). Due to the need to protect the health of employees, the values of the permissible vibration level at the workplace are expressed as an acceleration of vibrations, the unit of which is $\mathrm{m} / \mathrm{s}^{2}$. Considering the criterion of the place of vibration penetration into the human body, it is divided into:

- general vibrations,

- local vibrations.

General vibrations penetrate the human body through lower limbs and part of the torso, especially through the pelvis and/or back, while local vibrations get into the body of the worker through the upper limbs (Koradecka, 2008). Vibrations of a general nature are, among others:

- floors, platforms, platforms in production halls and other rooms where work stations are located,

- steel structures subjected to mechanical treatment,

- vibrating platforms,

- seats and floors in means of transport,

- seat and floor of construction machinery (Lis \& Nowacki, 2005, Holka, 2011). Mechanical vibrations were classified as harmful factors in the work environment, therefore, the permissible values (NDN) were established for them. In general vibrations, daily exposure $A(8)$ is expressed as the eighth equivalent vibration acceleration, calculated as the dominant (highest) effective value of frequency-corrected vibration acceleration, from the determined values of the three directional components including the appropriate coefficients of 1.4 awx, 1.4awx, awz. In case of general vibrations, the value of daily exposure $A(8)$ should not exceed $0.8 \mathrm{~m} / \mathrm{s}^{2}$, and the value of short-term exposure (lasting 30 minutes and shorter) aw 30 min should not exceed $3.2 \mathrm{~m} / \mathrm{s}^{2}$. 
Mechanical vibrations are transmitted from the source of vibrations to the part of the worker's body in contact with the vibrating elements of machines, devices or structures. The influence of vibrations on the body may be dependent on many factors, i.e:

- values of parameters describing vibrations - frequency, speed, acceleration, mileage, duration of vibrations and direction of operation,

- the place of transmission of vibrations to a person and the position of their reception,

- individual physiological characteristics of the employee,

- current mental state (Kardas-Cinal, 2016)

The level of human-tolerated vibration depends to a greater extent on the magnitude of acceleration than on the amplitude of vibrations. The living organism has a natural ability to damp vibrations in many frequencies. This ability determines the natural frequency of the human body, which is about $5 \mathrm{~Hz}$. When the frequency of the vibrations of the environment is equal to the natural frequency of the human body (or its part), then the amplitude of the frequency of vibrations of the human body increases (Stasiów, 2001).

During long-lasting impact of vibrations in tissues, organs and human systems irreversible acute or chronic changes occur. After exceeding the adaptive capacity of the body, employees notice health changes commonly referred to as vibrational disease. The vibration syndrome may be vasomotor, osteoarticular or mixed. Excessive general vibrations cause vestibular disturbances, intervertebral cartilage defects, joint sagging, rebuilding of the bone tissue of the spine and radiculitis (Vihlborg et al., 2017, Solecki, 2011). Unfavourable changes in internal organs, occurring as a result of general vibrations, are mainly the result of stimulation of individual organs to resonance vibrations. It results from the natural frequency of human organs, whose values are in the range of 2-18 Hz (Charles, 2018). General vibrations with frequencies in this range and values of accelerations exceeding a certain threshold value, may cause vibrations of organs of dangerous amplitude, which may result in the appearance of disorders in the body's activities in the form of, inter alia, internal bleeding, petechiae, or mechanical organ disruption. The most common are adverse changes in the functions of the organs of the digestive system, including mainly the stomach and esophagus. Surveys of professionally exposed to general vibrations indicate that disorders also occur, among others in the vestibulo-cochlear organ, organs of the reproductive system of women, chest organs, nasopharyngeal organs (Koradecka, 2008).

With simultaneous action of general and local vibrations in employees, there is vegetative neurosis, central nervous system disorders and polyneuritis. The less drastic effects of vibration are:

- increased reaction time,

- increasing the time of visual reaction,

- interference in the coordination of movements,

- excessive fatigue, insomnia, irritability,

- memory impairment (Sorin et al., 2016). 
In order to minimize the undesirable impact of mechanical vibrations on the human during work, vibrations should be suppressed (Panda, 2017). Vibration damping is a physical phenomenon whose essence is the dissipation of mechanical energy. Internal attenuation in metals, being an element of basic sources of vibrations, is insignificant (Mayer, 2014). Therefore, to suppress vibrations, it is recommended to use additional damping layers, single or multilayer. As a result, the amplitude of the vibration displacement, the faster disappearance of free vibrations and the attenuation of the waves propagating in the elastic elements are obtained. The most recommended damping layers include polymers, elastomers, organic glasses, rubbers, felt and bituminous materials. In order for these materials to full fill their function, they should have the following properties:

- high damping ability,

- low specific gravity,

- low hygroscopicity,

- non-flammability,

- lack of corrosive activity,

- durability (Sikora, 2011, Sikora 2013).

In industrial conditions, especially in the metal industry, workers are exposed to vibrations transmitted through the ground on which they work. They often stand on the ground, which is the subject of technological processing, and their professional activities generate vibrations (Łakomy et al., 2017, Troitskiy et al., 2017, Venglár et al., 2018). In such situations, technical means in the form of vibroisolatators, such as: platforms, are used for human protection. antivibration, anti-vibration mats and plates or cushions (Engel \& Zawieska, 2010). As a material for building vibro-shock absorbers, the following are most commonly used:

- metal components,

- plastics (e.g. polyurethane, polystyrene),

- natural materials (e.g. rubber, cork, mineral fibber).

\section{RESEARCH MATERIAL}

In the conducted research, a polyurethane foam was selected as a research material, which is a plastic material consisting of solid polyurethane cells surrounded by gas bubbles, usually carbon dioxide. Polyurethane is the result of the reaction of polyesters containing free hydroxyl groups with isocyanate, polyols or polyether's. The main intermediate for the production of foam is a liquid mixture of raw materials with a density of about $1000 \mathrm{~kg} / \mathrm{m}^{3}$. The mixture includes additional auxiliaries such as: catalysts, surfactants, blowing agents, fillers, pigments, flame retardants (Swinarew, 2014, Pielichowski \& Puszyński, 2015).

Polyurethane materials are used in the refrigeration industry, automotive industry, furniture industry, construction and other sectors of the economy. Due to the growing supply of polyurethane materials, the problem of remaining waste appears. The dominant global trends emphasize the development of new 
technologies for the recycling of porous materials (Barnat et al., 2011, Małysa et al., 2016). Waste polyurethane foams found in many everyday products should be recovered and re-used for ecological and economic reasons. Waste may be a raw material for the production of new products or be a partial substitute for the original raw material (Gómez-Rojo et al., 2019).

In the area of occupational safety, primary products as well as those obtained from waste flexible and rigid foams used as secondary foamed polyurethane foams, as vibration and noise damping mats in production halls and in car cabs, floor insulation mats in production halls and acoustic insulation in soundabsorbing screens (Małysa et al., 2016).

For the construction of the original damping mats, commercially available refoamed polyurethane foams were used, with the densities declared in the range of $40-220 \mathrm{~kg} / \mathrm{m}^{3}$ declared by the manufacturer. Fig. 1 shows selected polyurethane foams with densities of 40,100 and $180 \mathrm{~kg} / \mathrm{m}^{3}$.
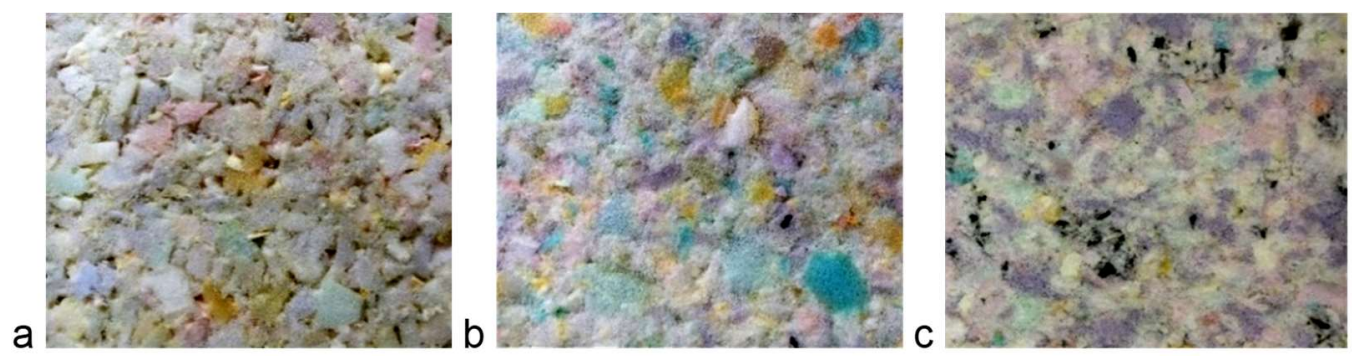

Fig. 1 Polyurethane foams:

a - polyurethane foam with a density of $40 \mathrm{~kg} / \mathrm{m}^{3}$,

b - polyurethane foam with a density of $100 \mathrm{~kg} / \mathrm{m}^{3}$,

c - polyurethane foam with a density of $180 \mathrm{~kg} / \mathrm{m}^{3}$

Layer systems were studied, concerning mats constructed from 1 to 3 layers of polyurethane foam. They were joined together by means of glue. In order to secure the systems to the steel structure on which the tests were carried out, a magnetic foil with a thickness of $0.5 \mathrm{~mm}$ was affixed to each of the tested systems using glue. In connection with the above, single-layer systems consisted of alternating layers of magnetic foil, glue and polyurethane foam (PU), while three-layer systems made of magnetic foil, glue, foam, glue, foam, glue and PU foam. For the construction of mats, foamed polyurethane foams with a thickness of 2, 4 and $6 \mathrm{~cm}$ were used.

\section{THE RESEARCH METHODOLOGY}

The tests of the effectiveness of damping mechanical vibrations of steel constructions were carried out in laboratory conditions in eight stages. The first stage was the selection and preparation of research material. At the same time, the research stand was designed and built. Then, vibration damping measurements were taken and the obtained results were statistically processed. The fifth stage of the research was the interpretation of the results obtained. Based on the obtained research results, in subsequent stages, factors influencing the properties of suppressing systems were identified and the 
method of selection of damping systems was elaborated, which in the final stage was verified in industrial conditions.

The research material, as previously described, was layered vibroacoustic systems (vibration-isolating), built on the basis of foamed polyurethane foam secondarily. Layer systems used for research, in the work content are also called mats, systems, damping systems.

A proprietary test stand was designed and built, imitating the process of machining steel structure, e.g. chiselling, grinding or hammering, as well as general vibrations which affect the worker accompanying this process (Fig. 2).

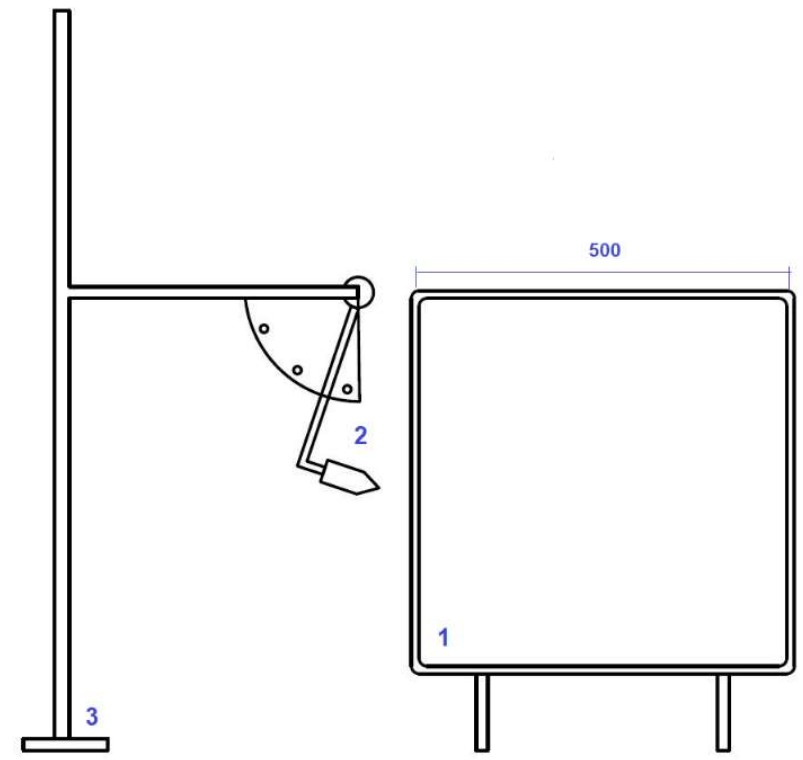

Fig. 2 Scheme of the stand for the vibration damping test: 1 - steel cube, 2 - steel vibration exciter, 3 - stand

The main element of the test bench is a steel cube, with dimensions $500 \times 500$ $\mathrm{mm}$. In the construction, four walls are a solid surface, while two opposite sides are left empty. This construction provides unrestricted access to each of the four walls, both for measuring and locating vibration dampening systems. The cube was placed on an even and stable ground, eliminating the perceived causes of measurement disturbances related to the operation of the building. The support for the construction were four steel legs, finished with rubber vibro-shock absorbers. While building the test stand, structural steel was used, which allowed to place a magnetic vibration sensor cooperating with the meter on the surface of the test stand. During the measurements, the vibration transducer was located at the intersection of the symmetry axis, on the upper surface of the test bench. The point was determined in preliminary studies confirming the lack of significant relationships between the results and the location of the transducer. Mechanical vibrations were pulsed through a steel weight that strikes one of the side walls of the structure. The inductor was mounted on a stand and released from a fixed height, which ensured impact with reproducible force (Łakomy et al., 2017). 
Measurements of vibration acceleration were carried out for created magnetic mats attached to the walls of the structure. The location of one-, two- and three-layer structures on the test stand is shown in Fig. 3.
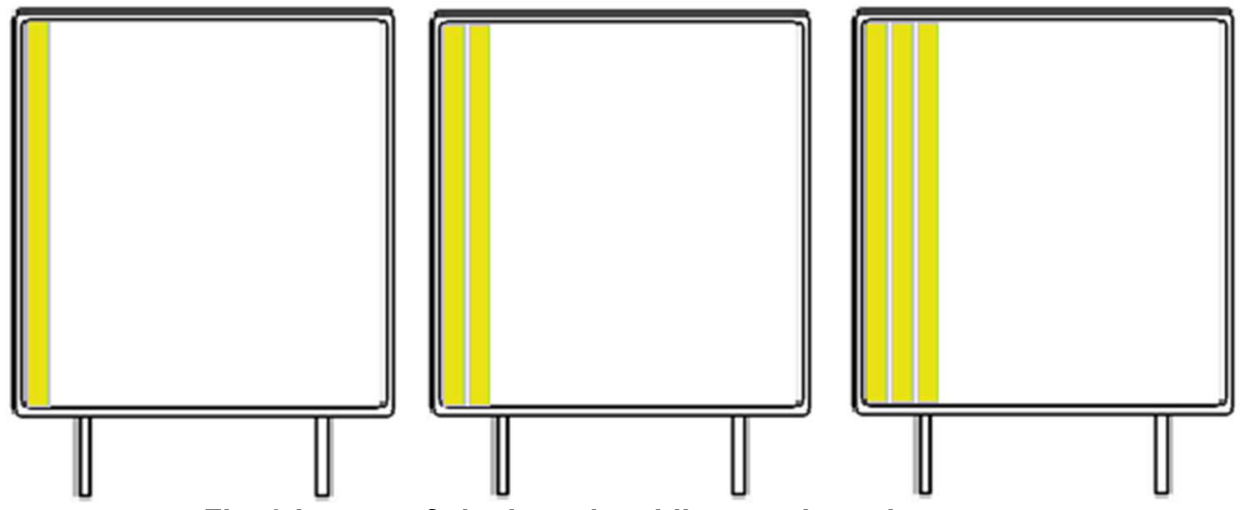

Fig. 3 Layout of single and multilayer polyurethane mats

Then the weight was released and the acceleration of vibrations generated by the inductor impact was measured. The measurement was carried out for 10 seconds. The tests were carried out for each type of damping system, obtaining a minimum of 20 results for individual mats. In the case of large differences in the results, the measurements were repeated (Łakomy, et al, 2017).

To measure the acceleration of mechanical vibrations, a four-channel digital SVAN 958 meter was used, which allowed narrow-band analysis and analysis in one-third bands. The measurements were made using a three-axis acceleration transducer to measure local and general vibrations.

The effectiveness of vibration damping was determined as the difference of vibration acceleration of the structure without the use of damping mats and their application in accordance with formula 1. This difference, for comparison purposes, was presented in relation to the average of vibration acceleration measurements of the unloaded structure (without mats). In connection with the above, the term "damping efficiency" is understood as the percentage of reduction of vibration acceleration.

$$
\text { S_TD }=\left(1-\left(\left(X \_O B C\right) / X \_B E Z\right)\right) \cdot 100 \%
$$

where:

STD - effectiveness of vibration damping

$\mathrm{XOBC}$ - the arithmetic mean of the results of vibration acceleration measurements using a damping mat,

$\mathrm{XBEZ}$ - the arithmetic mean of the vibration accelerations of the unloaded structure.

In order to develop the obtained test results more easily the damping properties of the analyzed layered systems were coded. The suppression results were divided into classes, every $10 \%$, by assigning them codes by Table 1 . Thanks to such a division, knowing the expected minimum damping properties of layered structures, you can quickly select them, e.g. by expecting the suppressing properties at the level of $78 \%$ in a given frequency, the systems with code 7 and higher at this frequency will be selected (Łakomy \& Nowacki, 2019). 
Table 1 Codes of vibration damping effectiveness

\begin{tabular}{|c|c|c|c|c|c|c|c|c|c|c|}
\hline $\begin{array}{c}\text { Effectiveness } \\
\text { of damping } \\
\text { vibration } \\
{[\%]}\end{array}$ & $\begin{array}{l}\frac{0}{1} \\
0\end{array}$ & $\begin{array}{l}\text { N } \\
\check{\leftarrow} \\
\leftarrow\end{array}$ & $\begin{array}{l}\stackrel{p}{1} \\
\stackrel{1}{N}\end{array}$ & $\begin{array}{l}\frac{P}{+} \\
\frac{1}{m}\end{array}$ & $\begin{array}{l}0 \\
1 \\
1 \\
\dot{y}\end{array}$ & $\begin{array}{l}8 \\
1 \\
15\end{array}$ & $\begin{array}{l}? \\
1 \\
\frac{6}{6}\end{array}$ & $\begin{array}{l}\infty \\
\infty \\
1 \\
\kappa\end{array}$ & $\begin{array}{l}\text { ه } \\
\frac{1}{\infty}\end{array}$ & $\frac{8}{\frac{8}{1}}$ \\
\hline $\begin{array}{l}\text { Damping } \\
\text { code }\end{array}$ & 0 & 1 & 2 & 3 & 4 & 5 & 6 & 7 & 8 & 9 \\
\hline
\end{tabular}

\section{VIBRATION REDUCTION METHOD DURING GRINDING}

The method of selection of damping vibroacoustic systems was verified on two industrial examples, and it concerned the reduction of vibrations and noise of the audible grinding process of a steel structure (Fig. 4). In the first example, 30 $\mathrm{mm}$ thick steel was machined. The vibration transducer was placed directly next to the grinder's contact point with the steel structure.

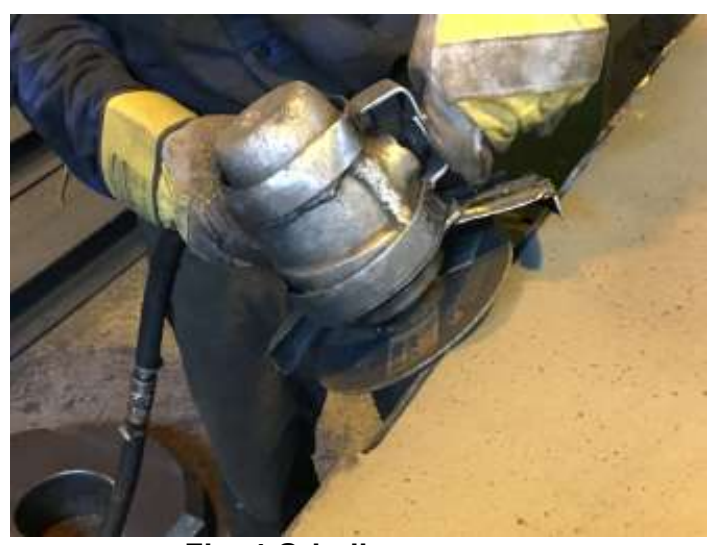

Source: own elaboration

Fig. 4 Grinding process

The course of vibration accelerations in the entire measured frequency range is shown in Fig. 5, and from the entire vibration spectrum, for the further analysis, 20-200 Hz oscillation was selected (Figure 6).

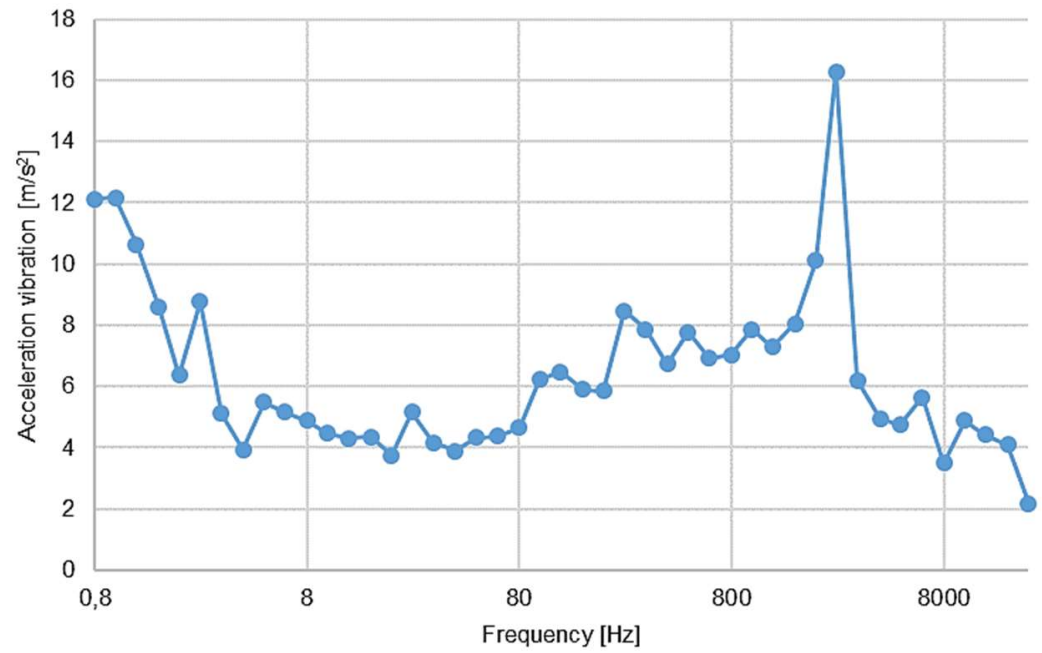

Fig. 5 Vibrations of steel structure during machining (frequency range $\mathbf{0 . 8 - 2 0 0 0 0 ~ H z}$ )

The rationale for choosing this frequency range is the greatest, harmful effect of vibration on the worker's body occurring from 20 to $200 \mathrm{~Hz}$ (Koradecka, 2008). 
The vibration acceleration values are marked orange, while the vibration acceleration values corrected in accordance with the general vibration correction curve are marked blue.

In the analyzed frequencies, the hygienic standard for general vibration for a day-long exposure to hazards of $0.8 \mathrm{~m} / \mathrm{s}^{2}$ was accepted as a criterion, as indicated by the horizontal line on the graph (Figure 6).

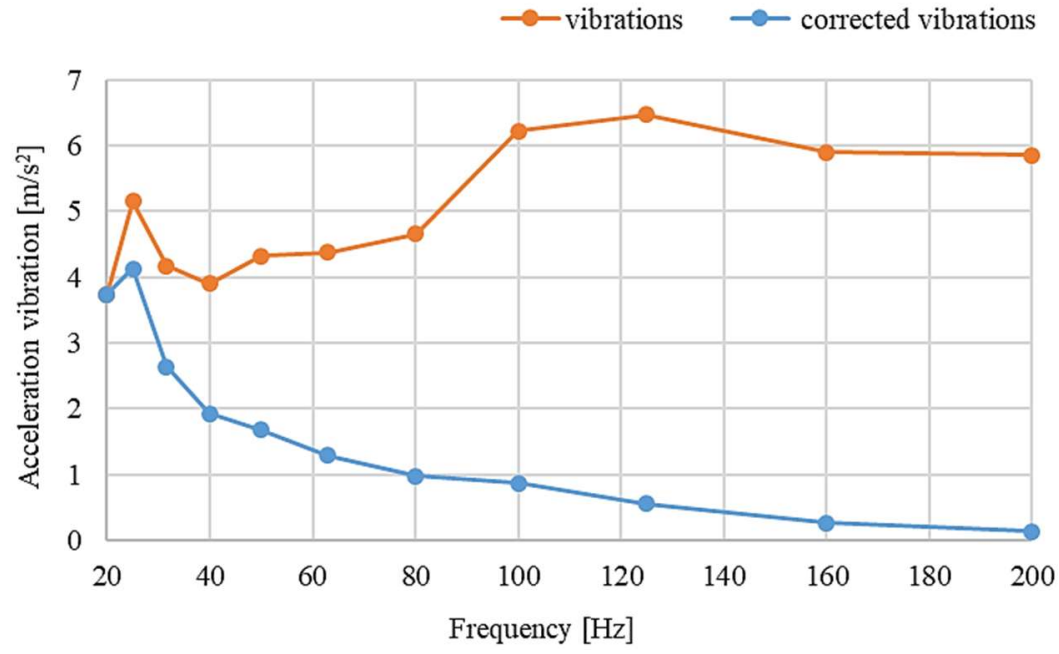

Fig. 6 Vibrations of the steel structure during machining (frequency range $20-200 \mathrm{~Hz}$ )

In the described case, it was found that there is a need to reduce the level of vibrations in eight frequencies, i.e. $20,25,31.5,40,50,63,80,100 \mathrm{~Hz}$. The values of vibration acceleration in the above-mentioned frequencies, together with the percentage of the reduction of vibration acceleration and the assigned minimum damping code of layer systems, are presented in Table 2.

- with a density of $40 \mathrm{~kg} / \mathrm{m}^{3}$, two- or three-layer, with a thickness of $4 \mathrm{~cm}$ and 6 $\mathrm{cm}$,

- with a density of $60 \mathrm{~kg} / \mathrm{m}^{3}$, two- or three-layered, with a thickness of $4 \mathrm{~cm}$ and $6 \mathrm{~cm}$.

The last stage of the selection of damping systems is carried out in terms of ergonomic aspects. Considering the mass of the systems, the recommended vibration damping system, in the analyzed grinding process, is the lightest 40.4 thick, $4 \mathrm{~cm}$ thick, consisting of two layers of polyurethane foam.

Table 2 Acceleration of vibrations and expected damping properties of multilayer systems

\begin{tabular}{|l|c|c|c|c|c|c|c|c|}
\hline & \multicolumn{7}{|c|}{ Vibration frequency [Hz] } \\
\cline { 2 - 9 } & 20 & 25 & 31,5 & 40 & 50 & 63 & 80 & 100 \\
\hline Acceleration vibration $\left[\mathbf{m} / \mathbf{s}^{\mathbf{2}}\right]$ & 3.75 & 4.13 & 2.64 & 1.93 & 1.68 & 1.29 & 0.98 & 0.88 \\
\hline Reduction of vibration acceleration [\%] & $79 \%$ & $81 \%$ & $69 \%$ & $58 \%$ & $52 \%$ & $38 \%$ & $19 \%$ & $9 \%$ \\
\hline Minimum damping code & $\mathbf{7}$ & $\mathbf{8}$ & $\mathbf{6}$ & $\mathbf{5}$ & $\mathbf{5}$ & $\mathbf{3}$ & $\mathbf{1}$ & $\mathbf{0}$ \\
\hline
\end{tabular}

Table 3 Selection of vibration damping systems according to the damping code

\begin{tabular}{|c|c|c|c|c|c|c|c|c|c|}
\hline \multirow{2}{*}{ Name regime } & \multirow{2}{*}{ Thickness regime [cm] } & \multicolumn{6}{|c|}{ Vibration frequency [Hz] } \\
\cline { 3 - 10 } & & 20 & 25 & 31,5 & 40 & 50 & 63 & 80 & 100 \\
\hline $\mathbf{4 0 . 4}$ & $2+2$ & 8 & 8 & 8 & 8 & 7 & 8 & 6 & 3 \\
\hline $\mathbf{4 0 . 5}$ & $2+2+2$ & 8 & 8 & 8 & 8 & 7 & 8 & 6 & 4 \\
\hline $\mathbf{6 0 . 4}$ & $2+2$ & 8 & 8 & 8 & 7 & 6 & 8 & 6 & 4 \\
\hline $\mathbf{6 0 . 5}$ & $2+2+2$ & 8 & 8 & 8 & 8 & 7 & 8 & 7 & 5 \\
\hline
\end{tabular}




\section{THE METHOD OF REDUCING AUDIBLE NOISE DURING GRINDING}

Mechanical machining of the steel structure also generates acoustic phenomena (noise), the possibility of reduction of which was analyzed in the second example of the selection of the damping systems. Measurements of vibration acceleration and audible noise were made, as in the first example, during grinding. The workpiece was steel with a thickness of $40 \mathrm{~mm}$. Fig. 7 shows the course of audible noise and vibration acceleration.

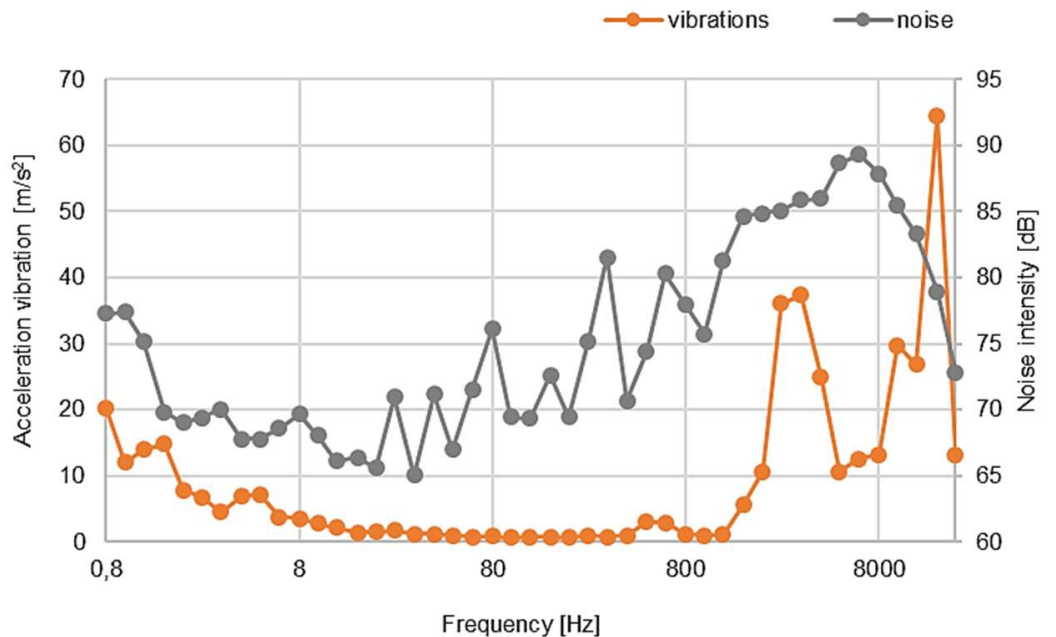

Fig. 7 Vibrations and audible noise emitted during grinding of steel structure (frequency range $0.8-20000 \mathrm{~Hz}$ )

Diagram (Fig. 8) presents the course of noise intensity measurement at onethirds frequencies. The results of the noise intensity measurements were marked on the graph in gray, while the blue color was marked with the corrected results of the A correction curve corresponding to the biological sensitivity of the organism to noise. An 8-hour, continuous exposure to noise was assumed, therefore the NDS value of $85 \mathrm{~dB}$, marked on the graph by the horizontal line, was assumed as the reduction target.

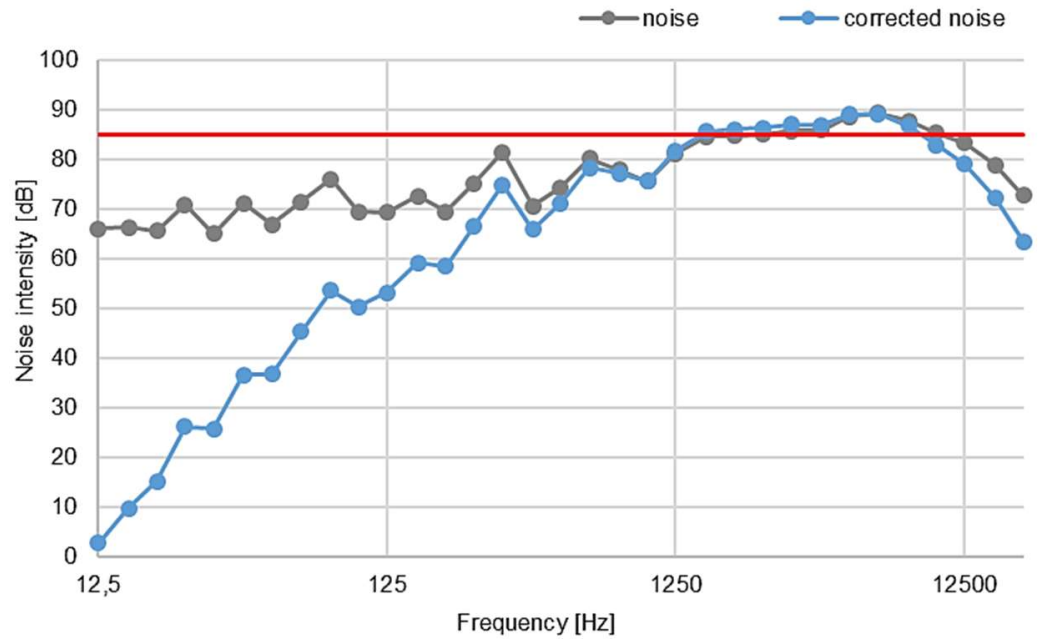

Fig. 8 The audible noise emitted during the grinding of the steel structure (frequency range 12.5-20000 Hz) 
It was found that normative values were exceeded in seven frequencies, i. e 2.5, $3.15,4,5,6.3,8$ and $10 \mathrm{kHz}$. Table 4 shows, in percentage terms, the necessary noise reduction, along with the minimum damping codes assigned to these values.

Table 4 Noise intensity and expected damping properties of multilayer systems

\begin{tabular}{|c|c|c|c|c|c|c|c|}
\hline \multirow[t]{2}{*}{ 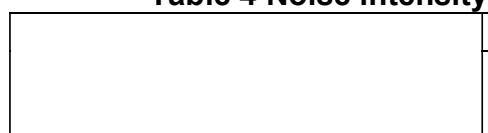 } & \multicolumn{7}{|c|}{ Vibration frequency [Hz] } \\
\hline & $\begin{array}{l}\text { 오 } \\
\text { N }\end{array}$ & $\frac{\circ}{\infty}$ & ষ্ণ & 응 & 옹 & ○ & 8 \\
\hline Noise intensity [dB] & 85.1 & 85.88 & 85.99 & 88.67 & 89.34 & 87.86 & 85.45 \\
\hline Noise reduction [\%] & $1 \%$ & $18 \%$ & $21 \%$ & $55 \%$ & $60 \%$ & $49 \%$ & $5 \%$ \\
\hline Minimum damping code & 0 & 1 & 2 & 5 & 6 & 4 & 0 \\
\hline
\end{tabular}

Selection of the analyzed systems damping vibrations was performed, and the results are presented in Table 5.

Table 5 Selection of silencing systems according to the damping code

\begin{tabular}{|c|c|c|c|c|c|c|c|c|}
\hline \multirow[b]{2}{*}{$\begin{array}{l}\text { Name } \\
\text { regime }\end{array}$} & \multirow[b]{2}{*}{$\begin{array}{l}\text { Thickness } \\
\text { regime } \\
\text { [cm] }\end{array}$} & \multicolumn{7}{|c|}{ Vibration frequency [Hz] } \\
\hline & & \& & $\frac{\circ}{\infty}$ & ○ & $\begin{array}{l}\text { 오 } \\
\text { ○ }\end{array}$ & $\begin{array}{l}\text { ○ } \\
\text { లె }\end{array}$ & $\begin{array}{l}\text { ○ } \\
\text { ○ }\end{array}$ & $\begin{array}{l}\text { 응 } \\
\text { 으 }\end{array}$ \\
\hline 100 & 4 & 5 & 6 & 6 & 6 & 6 & 5 & 4 \\
\hline 160 & 4 & 5 & 5 & 6 & 6 & 6 & 6 & 5 \\
\hline 180 & 4 & 5 & 5 & 6 & 6 & 6 & 5 & 5 \\
\hline 200 & 4 & 5 & 5 & 6 & 6 & 6 & 5 & 5 \\
\hline 200 & 6 & 5 & 6 & 6 & 6 & 6 & 5 & 6 \\
\hline 220 & 2 & 4 & 5 & 6 & 6 & 6 & 5 & 4 \\
\hline 220 & 4 & 5 & 5 & 6 & 6 & 6 & 6 & 5 \\
\hline
\end{tabular}

In the analyzed case, the systems meeting the assumed criteria are mats built on the basis of PU foams:

- with a density of $100 \mathrm{~kg} / \mathrm{m}^{3}$, single-layered, $4 \mathrm{~cm}$ thick,

- with a density of $160 \mathrm{~kg} / \mathrm{m}^{3}$, single-layered, $4 \mathrm{~cm}$ thick,

- with a density of $180 \mathrm{~kg} / \mathrm{m}^{3}$, single-layered, $4 \mathrm{~cm}$ thick,

- with a density of $200 \mathrm{~kg} / \mathrm{m}^{3}$, single-layered, $4 \mathrm{~cm}$ and $6 \mathrm{~cm}$ thick,

- with a density of $220 \mathrm{~kg} / \mathrm{m}^{3}$, single-layered, with a thickness of $4 \mathrm{~cm}$ and 6 $\mathrm{cm}$.

In the case of reducing audible noise, the lightest foam was the lightest one available, 100.2, single layer, $4 \mathrm{~cm}$ thick. The choice was made based on the criterion of the lowest mass of the system.

\section{SUMMARY}

Verification of vibrations reduction methods or noise during grinding were carried out in industrial conditions. At the same time, measurements of audible noise were made with the measurement of vibrations. On the basis of the damping properties of polyurethane layered systems known from laboratory tests, a method of selecting systems meeting the assumed requirements was presented. The basis of the method is the knowledge of vibration damping properties in individual frequencies for the analyzed systems. Two examples of the use of the selection method in practice are presented. In each case, 
measurements of vibration and/or noise acceleration were made. The results were corrected in accordance with selected the methodology. As a criterion in the selection of dominant frequencies at the tested workplace, hygienic standards were adopted: for vibrations with a value of $0.8 \mathrm{~m} / \mathrm{s}^{2}$ corresponding to an all-day exposure to general vibrations; for noise, the NDN value of $85 \mathrm{~dB}$, assuming a day-long exposure to noise. The frequencies at which exceedances of norms were recorded were determined. For the analyzed examples, technical solutions meeting the requirements for damping mechanical vibrations were selected and an ergonomically optimal variant was proposed.

On the basis of the verification of industrial data, the method of selection of systems suppressing the vibrations of the steel structure was correct. The possibility of selecting the damping material was confirmed, based on its damping properties in specific third bands, in which the predicted vibration acceleration levels were previously detected. The method can be used both in the reduction of general vibrations and audible noise in various industries, for example in the maintenance of steel structures.

\section{REFERENCES}

Barnat W., Miedzińska D., Niezgoda T. (2011). Poliurethane foams - properties, applications, recycling, Archives of Waste Management and Environmental Protection, 4, pp. 14-17.

Charles L., Mal C., Burchfiel C., et al. (2018). Vibration and Ergonomic Exposures Associated with Musculoskeletal Disorders of the Shoulder and Neck, Safety and Health at Work, 9, pp. 125-132.

Engel Z., Zawieska W. (2010). Hałas i drgania w procesach pracy - źródła ocena, zagrożenia, Wyd. Centralny Instytut Ochrony Pracy - Państwowy Instytut Badawczy, Warszawa.

Gómez-Rojo R., Alameda L., Rodríguez A. et al. (2019). Characterization of Polyurethane Foam Waste for Reuse in Eco-Efficient Building Materials, Polymers 11, pp. 359-369.

Indulski J. (red). (1999). Higiena pracy, Tom II, Wyd. Instytut Medycyny Pracy, Łódź.

Holka H. (2011). Drgania i dynamika maszyn, Wyd. Uczelniane Uniwersytetu Technologiczno-Przyrodniczego, Bydgoszcz

Kardas-Cinal E. (2016). Metody oceny komfortu wibracyjnego, Prace naukowe Politechniki Warszawskiej, Z. 112 Transport, pp. 165-174.

Koradecka D. (red.), (2008). Bezpieczeństwo i higiena pracy, Wyd. Centralny Instytut Ochrony Pracy - Państwowy Instytut Badawczy, Warszawa.

Lis T., Nowacki K. (2005). Zarządzanie bezpieczeństwem i higieną pracy w zakładzie przemysłowym, Wyd. Politechniki Śląskiej, Gliwice.

Łakomy K., Nowacki K. (2019). Metoda doboru ustrojów wibroakustycznych tłumiących drgania, Inżynieria Zarządzania - Kształtowanie środowiska i bezpieczeństwo pracy. Wyd. Polskie Wydawnictwo Ekonomiczne, Warszawa.

Łakomy K., Nowacki K., Lis T. (2017). Ocena bezpieczeństwa pracy przy użytkowaniu pras hydraulicznych. Innowacje w zarządzaniu i inżynierii produkcji. T. 2. Pod red. Ryszarda Knosali, Wyd. Oficyna Wydawnicza Polskiego Towarzystwa Zarządzania Produkcją, Opole, pp. 467-478.

Małysa, T., Nowacki, K., Lis, T. (2016) Assessment of the acoustic properties in octavo bands for selected polyurethane materials, Solid State Phenomena, vol. 246, pp. 7-10. 
Małysa, T., Nowacki K., Wieczorek, J. (2016). Assessment of sound absorbing properties of polyurethane sandwich system, Composites Theory and Practice, 16 (4), pp. 244-248.

Mayer D., Militzer J., Bein M. (2014). Integrated Solutions for Noise and Vibration Control in Vehicles, SAE, (01). pp. 2048-2043.

Pandaa K. C. (2016). Dealing with Noise and Vibration in Automotive Industry, 12th International Conference on Vibration Problems, ICOVP 2015, Procedia Engineering 144, pp. 1167-1174.

Pielichowski J., Puszyński A. (2015). Chemia polimerów, Wyd. Wydawnictwo Oświatowe FOSZE, Rzeszów.

Sikora J., (2011). Warstwy gumowe w rozwiązaniach zabezpieczeń wibroakustycznych, Wyd. AGH, Kraków.

Sikora J. (2013). Katalog nowych materiałów dźwiękochłonnych przydatnych w projektowaniu zabezpieczeń wibroakustycznych, Wyd. AGH, Kraków.

Solecki L. (2011). Bóle pleców w dolnej części kręgosłupa wśród rolników eksponowanych na wibrację ogólną - przegląd piśmiennictwa, Medycyna Pracy, 62/2, pp.187-202.

Sorin S., Toth L., Călămar A., et al., (2016). Safety and health at work concerning occupational exposure to noise in steel industry workers, 16th International Multidisciplinary Scientific GeoConference SGEM, pp. 547-555.

Stasiów B. (2001) Problemy diagnostyczne postaci kostno-stawowej zespołu wibracyjnego, Medycyna Pracy, 2, pp. 139-144.

Swinarew B. (2014). Poliuretany - nowoczesne wszechstronne materiały, Część II pianki poliuretanowe, Przetwórstwo Tworzyw, 3, pp. 252 - 259.

Troitskiy O.A., Skvortsov O. B., Stashenko V. (2017). Generation of mechanical vibrations in metal samples by the use of the pinch effect, IOP Conf. Series: Materials Science and Engineering, 218, pp. 12-20.

Uzarczyk A. (2006) Czynniki szkodliwe i uciążliwe w środowisku pracy, Wyd. ODDK, Gdańsk.

Venglár M., Sokol M., Ároch R. (2018). Ambient vibration measurements of steel truss bridges, Journal of Measurements in Engineering., 6-4, pp. 234-249.

Vihlborg P., Bryngelsson I.L., Lindgren B., et at. (2017). Association between vibration exposure and hand-arm vibration symptoms in a Swedish mechanical industry, International Journal of Industrial Ergonomics 62, pp. 77-81.

\begin{abstract}
.
It is the duty of every employer to provide its employees with safe, hygienic and ergonomic working conditions. Available information suggests that working conditions in Poland improve each year, thanks to the ever-growing security culture prevailing in Polish enterprises. In spite of everything, there is still a problem of hazards in the workplace, and special attention should be paid to acoustic threats - vibrations and audible noise. Although entities operating on the market offering comprehensive services to reduce the exposure of employees to vibroacoustic hazards, there is still a need to develop new methods to protect the health of employees. Excessive exposure to vibrations and noise is associated with negative health effects that are exposed to, among others, employees involved in the mechanical processing of steel structures. Employees also experience the impact of local and general vibrations. Local vibrations can be relatively easily eliminated using anti-vibration gloves, while the reduction of general vibrations is often an unresolved problem for employees and employers. The publication presents the results of research on the development of the method of damping mechanical vibrations generated during grinding steel constructions. The research included several stages, among others: selection and preparation of the research material, design and construction of the test stand, measurements of vibration acceleration and industrial verification of the obtained results.
\end{abstract}

Keywords: vibrations, noise, work safety 